\title{
Environmental Justice Goes Underground? Historical Notes from Canada's Northern Mining Frontier
}

\author{
Arn Keeling and John Sandlos
}

\begin{abstract}
Industrial mining in Canada's territorial north has produced negative social, economic, and environmental consequences for aboriginal communities in the region since the early twentieth century. Many of these historical impacts persist: toxic sites associated with abandoned mines located within aboriginal traditional territories have become a source of great concern in recent years. It is difficult, however, to analyze historic mining activity within the traditional siting debate that has dominated the environmental justice movement in North America, as mining companies invariably locate where economic ore bodies exist. Instead, we argue that northern mining conflicts might best be understood through a productive alliance of North American environmental justice with insights from political ecology, a sub-discipline that has traditionally focused on environmental injustices in Third World settings, particularly local conflicts over access to resources that originate with colonialism and the expansion of global capital.
\end{abstract}

I N THE MID-1990s, representatives of the Sahtu Dene, an aboriginal group from the Great Bear Lake region of the Northwest Territories, travelled to Ottawa to demand health and environmental studies to determine the past, present, and future impacts of radiation exposures from historical uranium mining on both workers and the community. After numerous rebuffs, the community finally secured an agreement with the Canadian government to undertake joint historical, scientific, and epidemiological studies to determine the impact of uranium mining in its territory. ${ }^{1}$ These reports, and testimony by Dene people, recounted the advent of radium and uranium mining in the region in the 1930s, including the

Dr. Keeling is Assistant Professor, Department of Geography, at Memorial University of Newfoundland. Dr. Sandlos is Assistant Professor and Graduate Coordinator, Department of History, also at Memorial University of Newfoundland. Research for this article was undertaken with the support of a Social Sciences and Research Council of Canada Research Development Initiatives Grant. The authors wish to thank fellow panelists at the Canadian Association of Geographers/International Symposium of the Cultural Approach in Geography joint conference in Québec City, 2008, for feedback on an earlier version of this argument. We would also like to thank Julia Laite and JeanSébastien Boutet for their input on an early draft of the article. We assume full responsibility for any errors or omissions.

${ }^{1}$ Canada-Déline Uranium Table. Action Plan. (Ottawa: Northern Affairs Program, December 2002). development of the mine, an ore concentration facility, transportation network, and the service town of Port Radium. Although the mine closed briefly in 1940 in response to collapsing radium prices, it reopened in 1942 and was subsequently nationalized by the Canadian government in 1944 to secure uranium supplies for the Allied atomic bomb project. ${ }^{2}$ During this period, the company hired local native people to perform unskilled work at the site and along the ore transportation route, including the loading and unloading of uranium ore in burlap sacks for barge transport along northern waterways to a railhead in Alberta. ${ }^{3}$ Not only were potential health and safety concerns associated with native workers handling dusty (and far from secure) sacks filled with radioactive material ignored, but the company operated with little concern for the broader environmental hazards connected to radium and uranium production, dumping radioactive tailings directly into Great Slave Lake, local pothole lakes, and on land near Port Radium. ${ }^{4}$

\footnotetext{
${ }^{2}$ Robert Bothwell. Eldorado: Canada's National Uranium Company. (Toronto: University of Toronto Press, 1984).

${ }^{3}$ Peter C. Van Wyck, "The Highway of the Atom: Recollections Along a Route," Topia 7 (Spring 2002), 99-115.

${ }^{4}$ Intertec Management Ltd. Port Radium Fact Finder Report (Regina: Intertec, 2004). Protection was also inadequate for nonaboriginal workers in the mine and mill operation. See Gordon H.E.
} 
Uranium mining at Port Radium ceased in 1962 (though silver was mined until 1982), but the toxic legacy of the abandoned mine later became a source of controversy as high rates of cancer among the ore carriers prompted national media coverage and two documentary films. ${ }^{5}$ Persistent aboriginal demands for action resulted in innovative collaborative government-community environmental and health studies and remediation plans. ${ }^{6}$ While these studies concluded that the levels of uranium exposure among aboriginal workers were not the direct cause of elevated cancer rates and that radioactive tailings sites are ecologically benign, the Sahtu Dene in Déline have disputed these findings. ${ }^{7}$ The community studies have also highlighted the deep psychological scars remaining for many of the generation who lived through this period and who associate the mine with the painful social and economic changes associated with industrial development. For people who benefited little from the resource wealth removed from their territory and who live with the environmental legacies of mining, a sense of bitterness and injustice remains. ${ }^{8}$

At first glance, the case of the Sahtu Dene and uranium mining might be understood through the lens of environmental justice. This history concerns a marginalized, racialized group that was exposed to environmental hazards not of their own making. The Dene experience connects to a wider history of what has been called "nuclear colonialism," the process by which uranium mining, nuclear waste siting, and nuclear testing has treated aboriginal territories in North America as "sacrificial landscapes" in the global geopolitical struggles of the nuclear age. ${ }^{9}$ While the benefits of uranium mining accrued to private capital and the state, the environmental effects were disproportionately borne by local communities and landscapes. ${ }^{10}$ Arguably, this episode also follows a pattern of development that has characterized historic mining in Northern Canada generally, where recent studies have identified a legacy of environmental hazards in aboriginal territories. ${ }^{11}$ Many abandoned mines are located in proximity to aboriginal communities or important hunting and fishing territories. Some communities, like the Sahtu Dene, have undertaken what might be thought of as environmental justice activism to secure recognition, compensation, and remediation for mining's environmental impacts.

A closer examination suggests, however, that traditional environmental justice perspectives alone-with their emphasis on distributive injustice in waste siting decisions and the quantification of environmental inequity-are inadequate to comprehend the particular roots and dynamics of mining's unequal social and environmental legacies. Mineral development is not easily reducible to a siting issue within an environmental justice framework. As any mine developer will tell you, mines are sited where viable ore deposits are found, not necessarily where pliant or disenfranchised communities are located. In addition, aboriginal (and other) critiques of northern mineral development highlight a broader range of concerns than simply environmental contamination, including concerns about the social impacts of develop- ment and the connection of industrial mining to wider histories of dispossession, colonialism, and social change. This article will argue that a complete understanding of racial, social, and environmental inequities associated with historical mining activities in Canada's northern territories requires a conceptual blend of perspectives from environmental justice and political ecology, cognate fields that (strangely) have yet to engage in a sustained scholarly dialogue. We begin by briefly sketching the lineaments of large-scale mining development in the Canadian North, followed by a necessarily brief discussion of the applicability of perspectives from environmental justice and political ecology. We conclude with a call for a "historical political ecology" which considers the importance of regional political economies and histories of colonialism in framing how environmental injustice is

Sims. A History of the Atomic Energy Board of Canada. (Ottawa: Ministry of Supply and Services, 1981) and mine inspection files in the Library and Archives Canada, RG 85 Northern Affairs Program, Series D-1-A Vol. 200, file 555/107, Vol. 259 file 99-109, Vol. 260 file 99-109. On tailings deposit, see also Heather Myers. Uranium Mining in Port Radium, N.W.T: Old wastes, new concerns. (Ottawa: Canadian Arctic Resources Committee, August 1982) and Bothwell, Eldorado, 254-56.

${ }^{5}$ Andrew Nikiforuk, "Echoes of the Atomic Age: Cancer Kills Fourteen Aboriginal Uranium Workers," Calgary Herald, March 14, 1998: A1; A4; Randy Boswell, "Nuclear Shadow Finally Lifting Over 'Village Of Widows,'" The Ottawa Citizen, August 6, 2005: A3; Peter Blow (Dir.). Village of Widows (Lindum Films, 1999); David Henningson (Dir.). Somba Ke: The Money Place (Urgent Service Films, 2007).

${ }^{6}$ Canada-Déline Uranium Table, Action Plan, 2002.

${ }^{7}$ Canada-Déline Uranium Table. Final Report Concerning Health and Environmental Issues Related to the Port Radium Mine. (Ottawa: Indian and Northern Affairs Canada, 2005); Canadian Press, "Report Into Former N.W.T. Uranium Mine Recommends Immediate Remediation," September 6, 2005.

${ }^{8}$ If Only We Had Known: The history of Port Radium as told by the Sahtúot'ine (Déline, N.W.T.: Déline First Nation, 2005).

${ }^{9}$ Valerie L. Kuletz. The Tainted Desert: Environmental ruin in the American West. (New York: Routledge, 1998); Winona LaDuke and Ward Churchill, "Native America: The political economy of radioactive colonialism," Journal of Ethnic Studies 13, 3 (1985), 107-132.

${ }^{10}$ Doug Brugge and Rob Goble, "The History of Uranium Mining and the Navajo People," American Journal of Public Health 92 (September 2002), 1410-1419; Doug Brugge, Timothy Benally, and Esther Yazzie-Lewis. The Navajo People and Uranium Mining. (Albuquerque: University of New Mexico Press, 2006); Eric W. Mogren. Warm Sands: Uranium Mill Tailings Policy in the Atomic West. (Albuquerque: University of New Mexico Press, 2002); Ian Peach and Don Hovdebo. The Case for a Federal Role in Decommissioning and Reclaiming Abandoned Uranium Mines in Northern Saskatchewan (Regina: Saskatchewan Institute of Public Policy, 2003); Anna Stanley, "Citizenship and the Production of Landscape and Knowledge in Contemporary Canadian Nuclear Fuel Waste Management," The Canadian Geographer 52 (2008), 64-82.

${ }^{11}$ Office of the Auditor General of Canada. Report of the Commissioner of the Environment and Sustainable Development, 2002. (Ottawa: Minister of Public Works and Services, 2002), chapters 2 and 3. Since 2001, the federal Indian Affairs and Northern Development department has also assumed responsibility for dozens of contaminated sites associated with abandoned mines and military installations in the North through its Contaminated Sites Program. See Indian and Northern Affairs Canada. "Northern Contaminated Sites Program." $<$ http://www.ainc-inac.gc.ca/nth/ ct/ncsp/index-eng.asp $>$ (Last accessed January 2009). 


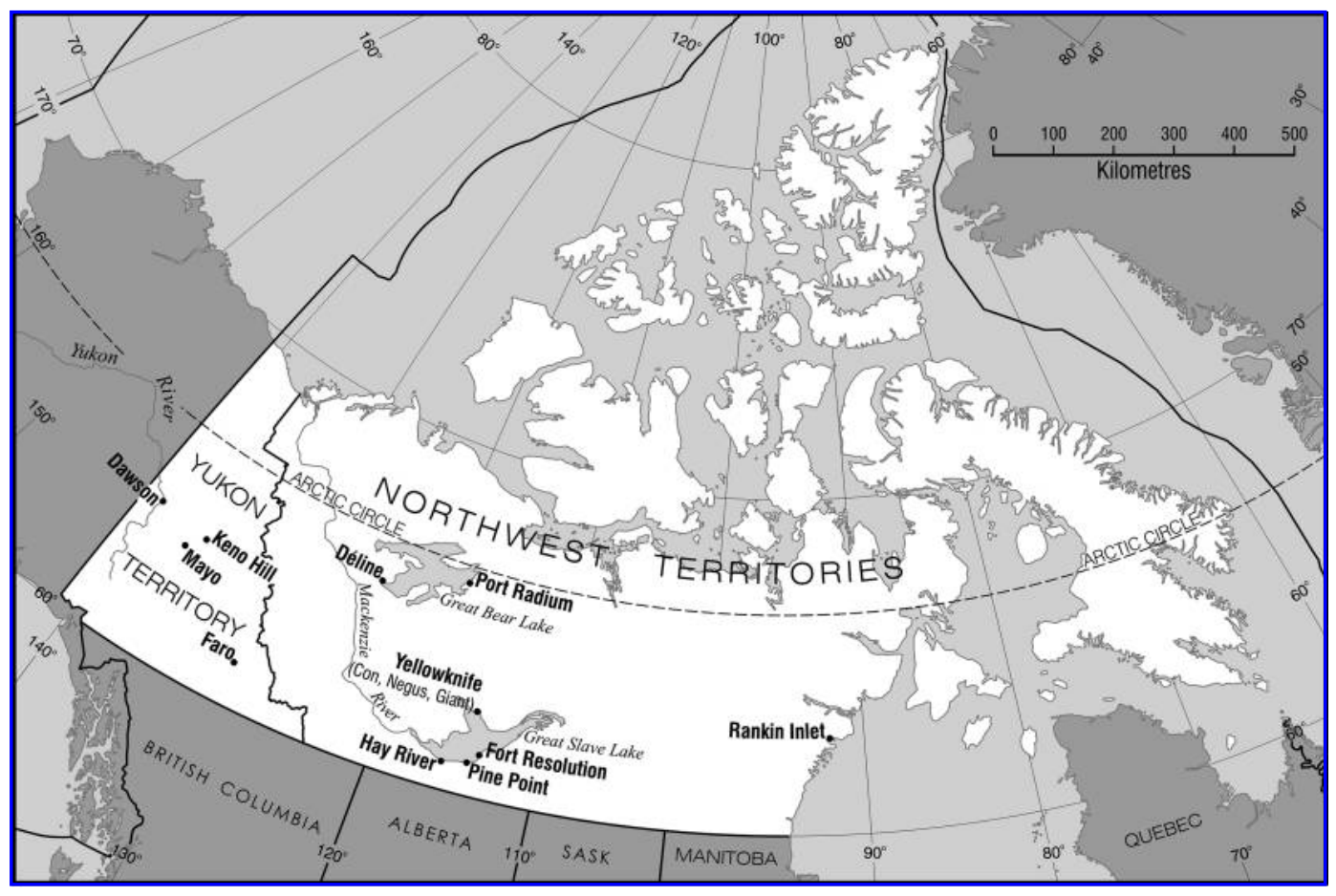

FIG. 1. Major historical mining sites and communities in Northern Canada.

understood, experienced, and contested in aboriginal communities.

\section{MINING IN NORTHERN CANADA}

Private sector mining interests began to develop largescale industrial mining projects in the Canadian North as the profitability of placer gold in the Klondike began to decline in the early twentieth century. Prior to 1945, mining activity was concentrated at only three main ore bodies across a vast territory: the Keno Hills Silver Mines near Mayo in the Yukon Territory, the radium/uranium mines around Port Radium, NWT, and the gold mines at Yellowknife, NWT (Figure 1). In the 1950s and 1960s, at the height of the post-war economic boom, mining companies proceeded with significant exploration and development activities at such sites as the lead-zinc deposits at Pine Point, NWT, lead deposits at Faro in the Yukon (the Cyprus-Anvil Mine), and nickel at Rankin Inlet, NWT. Despite the relatively small number and wide geographic dispersal of development sites, industrial mining activity had a transformative impact on the region. By the 1950s, metal mining and fuel production (the latter almost entirely for local consumption in industrial developments and settlements) accounted for over 80 percent of territorial economic output. ${ }^{12}$ More importantly, mining provided the impetus for the extension of southern Canadian capital, labor, and state power into formerly remote, predominantly aboriginal territories. As Morris Zaslow and Kenneth Rea recount, industrial mining operations spurred massive public and private investments in transportation infrastructure such as railways and airstrips, energy de- velopments such as hydroelectric projects, and industrial resource-extraction technologies such as underground mines and ore-concentration mills. ${ }^{13}$ Mining mega-projects also sketched new settlement patterns onto the landscape as several instant mining towns modeled on southern suburban design principles were built to house a largely imported workforce and their families. ${ }^{14}$

The new centers of mining activity carried dire environmental consequences for adjacent aboriginal communities. On the north shore of Great Slave Lake, for example, gold mining on a commercial scale began at Yellowknife in the 1930s with the development of the Con, Negus, and Giant mines and continued until 2005 with significant health and environmental impacts on the adjacent Dene communities of Dettah and Ndilo. ${ }^{15}$ The smelting of ore at the Giant mine site in particular resulted in local emissions of the carcinogenic arsenic trioxide (in addition to vast accumulations of the chemical in underground storage), with studies in the 1970s

\footnotetext{
${ }^{12}$ K.J. Rea. The Political Economy of the Canadian North. (Toronto: University of Toronto Press: 1968), 439.

${ }^{13}$ Rea, The Political Economy of the Canadian North; Morris Zaslow. The Northward Expansion of Canada, 1914-1967. (Toronto: McClelland and Stewart, 1988). Liza Piper refers to this as the "industrial assimilation" of northern environments in her "Harnessing the Wet West: Environment and Industrial Order on the Large Lakes of Subarctic Canada, 1921-1960." (PhD diss., York University, 2005).

${ }^{14}$ Zaslow, The Northward Expansion of Canada, 268.

${ }^{15}$ Office of the Auditor General of Canada. Report of the Commissioner of the Environment and Sustainable Development, 2002, chapter 2 .
} 
showing that $90 \%$ of aboriginal children had arsenic levels in their hair above safe levels of one part per million. ${ }^{16} \mathrm{~A}$ second emblematic example tells a similar story, as the Chipewyan Dene community of Fort Resolution experienced profoundly negative changes to the ecology of their local region when, in 1964, the Pine Point lead-zinc mine and community were established forty miles to the east along the south shore of Great Slave Lake. Through the 1950s and 1960s, exploration and development activities, including staking, drilling, the cutting of exploration lines, and the excavation of open pits, destroyed many Dene traplines, while competition for local game animals from the imported workforce further diminished hunting and trapping opportunities. In the 1970s, studies demonstrated that the mine tailings facility was prone to seasonal overflow and leakage, with waterborne heavy metals and sulfuric acid potentially impacting fish populations. ${ }^{17}$

For all these changes imposed on their communities and local environments, aboriginal northerners received few economic benefits from the mines. Aboriginal people traded with mining communities, and often participated in seasonal casual labor such as guiding, wood cutting, and meat hunting. But discriminatory hiring practices, a lack of training opportunities, cultural difficulties adjusting to industrial wage labor, and in some cases, difficulty commuting to the mines prevented any significant participation in the mining labor force. In 1968 aboriginal workers comprised only $3.4 \%$ of the workforce in the five mines located in Yukon Territory and 5.4\% in the six mines operating in the Northwest Territories. ${ }^{18}$ Company bunkhouses and northern mining communities reflected the values and desires of southern Canadians, and aboriginal people felt unwelcome in and often avoided towns such as Mayo, Yellowknife, and Pine Point. ${ }^{19}$ At the same time, northern aboriginal communities bore the full brunt of social impacts associated with sudden industrial development in the region, including drug and alcohol abuse, violence, and the sexual exploitation of women by a workforce composed largely of outsiders. ${ }^{20}$ Prior to the first negotiation of impact and benefit agreements in the 1970s, which gave aboriginal communities some input and participation in the development process, mining development represented for many aboriginal communities an appropriation of local resources, a risk to community health, and a threat to the contacttraditional economy of hunting and trapping.

\section{MINING AND ENVIRONMENTAL JUSTICE}

These and other histories of mining's negative environmental consequences and limited economic benefits for aboriginal communities carry obvious resonances with the core narratives of the environmental justice movement. Indeed, coarse evidence on the spatial distribution of mines in Canada suggests at least some affinity with the debate over the disproportionate siting of toxic facilities and waste sites near communities with large populations of racial minorities in the United States. ${ }^{21}$ One recent discussion paper, for example, indicates that roughly 1,200 aboriginal communities in Canada are situated within $200 \mathrm{~km}$ of active mines, with $36 \%$ of First Nations communities located within $50 \mathrm{~km}$ of a mine. ${ }^{22}$ In 2002, a report of the Canadian government's Commissioner of the Environment and Sustainable Development identified 30 abandoned mine sites in Canada's northern territories where the presence of toxins either required or may require remediation pending further assessment. ${ }^{23} \mathrm{~A}$ wider-ranging consultant's report from the year 2000 suggested that there were 160 abandoned mines in the territorial north, with 67 of these sites ${ }^{16}$ Lisa Sumi and Sandra Thomsen. Mining in Remote Areas:
Issues and Impacts. (Ottawa: MiningWatch Canada, 2001), 19.
Arsenic emissions were unregulated between 1949-1951, but
continued at low levels thereafter, resulting in local deposition of
arsenic in snow accumulation and watercourses. These emissions
became the subject of health and environmental studies in the
1970s: see Northwest Territories Archives, G-1993-006 Pollution
Control Division, File 10017119 vols. 1 and 2; James A. Plambeck
et al., "The Impact of Gold Smelter Emissions on Vegetation and
Soils of a Sub-Arctic Forest-Tundra Transition Ecosystem," Air
Pollution Control Association Journal 28 (1978), 133-138.
${ }^{17}$ For a summary see, Janet E. Macpherson, "The Pine Point
Mine." In Everett B. Peterson and Janet B. Wright (eds). Northern
Transitions, Volume I: Northern Resource Use and Land Use Policy
Study. (Ottawa: Canadian Arctic Resources Committee, 1978):
65-110.

${ }^{18}$ Northwest Territories Archives, Prince of Wales Northern Heritage Centre, G 2002-004, Box 23, S. Collymore, "Native Labour in the Northern Mining Industry," Unpublished Draft Paper, Department of Indian Affairs and Northern Development.

${ }^{19}$ Zaslow, The Northward Expansion of Canada, 186; Ken S. Coates. Best Left As Indians: Native-White Relations in the Yukon Territory, 1840-1973. (Montreal and Kingston: McGill-Queen's University Press, 1991); Paul Deprez. The Pine Point Mine and the Development of the Area South of Great Slave Lake. (Winnipeg: Center for Settlement Studies, 1973).

${ }^{20}$ For specific case studies of social impacts and employment issues at individual mines see Deprez, The Pine Point Mine; Janet E. Macpherson, "The Cyprus Anvil Mine." In Peterson and Wright, Northern Transitions, Volume I: 111-150; Claudia Notzke. Aboriginal Peoples and Natural Resources in Canada. (North York, ON: Captus University Publications, 1994), 216-217.

${ }^{21}$ Standard references for this type of work include United Church of Christ Commission for Racial Justice. Toxic Waste Sites and Race in the United States: A National Report on the Racial and Socio-Economic Characteristics of Communities with Hazardous Waste Sites. (New York: United Church of Christ, 1987); Robert D. Bullard. Dumping in Dixie: Race, Class and Environmental Quality, Second Ed. (Boulder, CO: Westview Press, 1994); Robert D. Bullard, Paul Mohai, Robin Saha, and Beverley Wright. Toxic Waste and Race at Twenty, 1987-2007: Grassroots Struggles to Dismantle Environmental Racism in the United States. (United Church of Christ, 2007). For overviews of environmental justice in Canada, see G. Keith Warriner, Kathleen McSpurren, and Alice Nabalamba, "Social Justice and Environmental Equity: Distributing Environmental Quality," Environments 29 (2001), 85-99; Dianne Draper and Bruce Mitchell, "Environmental Justice Considerations in Canada," The Canadian Geographer 45 (2001), 93-98; Randal Haluza-Delay, "Environmental Justice in Canada," Local Environment 12 (2007), 557-563.

${ }^{22}$ William Hipwell, Katy Mamen, Viviane Weitzner, and Gail Whiteman. Aboriginal People and Mining in Canada: Consultation, Participation and Prospects for Change: Working Discussion Paper. (Ottawa: North-South Institute, 2002), 4; Natural Resources Canada, Mining Information Kit for Aboriginal Peoples. <http://www .nrcan-rncan.gc.ca $/ \mathrm{mms} / \mathrm{pdf} / \mathrm{mining}$ toolkit.pdf $>$. Last accessed May 2008.

${ }^{23}$ Office of the Auditor General of Canada. Report of the Commissioner of the Environment and Sustainable Development, 2002, chapter 3. 
exhibiting either chemical contamination or physical instability; many of these mines are likely located within aboriginal territories. ${ }^{24}$ Such correlative data reveals very little, however, about the causal factors that lead to the establishment of mines in Northern Canada. As mentioned previously, the siting of mines near aboriginal communities was more incidental than intentional: mining companies located their operations where they found significant deposits of minerals and where existing or planned transportation routes allowed for the profitable exploitation of sub-surface resources. Furthermore, if one analyzes the territorial north as a distinct political entity (it is the only part of Canada where mining is regulated by the federal government), it would be difficult to demonstrate the imposition of disproportionate environmental impacts on aboriginal communities in the region because they formed a majority of the population in many areas. Where nonnative populations existed in large numbers, they tended to be white settlers living in mining communities that were subject to the same environmental hazards (in addition to occupational hazards) as aboriginal people.

Clearly, the case of aboriginal conflicts with mining operations demands conceptual frameworks that move beyond the statistical analysis of disproportionate environmental burdens that has dominated environmental justice scholarship in North America. Such an approach is not new, at least from a theoretical standpoint. As early as 1996 environmental justice scholars in the United States such as Pulido, Pellow, and Hieman were calling for research to expand beyond the narrow focus on quantitative proofs of environmental racism towards an examination of the qualitative or ideological manifestations of racism within environmental debates. They argued that environmental inequality could not be understood entirely within a liberal civil rights context (with its limited focus on distributional inequities), but must be analyzed alongside more structural forms of racism that are embedded in the historical expansion of colonialism and capitalism. ${ }^{25}$ In a closely related critique, many scholars have argued that the predominance of spatially delimited statistical research within the environmental justice literature ignores the multiple geographic scales-local, regional, national, or global-in which specific stories of industrial development and its attendant environmental injustice are situated. ${ }^{26}$ As Low and Gleeson have argued, "there is an urgent need for international environmental and ecological justice movements to transcend the 'politics of place' in order that the nature of industrial commodity production may itself be problematised." ${ }^{27}$ For all of these critics, to focus only on the uneven distribution of environmental hazards at the end of the production cycle risks ignoring the origins of environmental racism within broader forces such as global capital accumulation, industrial expansionism, and colonial or state-driven development strategies.

Though many do not explicitly employ the term environmental justice, several recent international studies of mining and aboriginal communities have adopted this increasingly nuanced view of environmental inequities. Studies from diverse places such as the Ok Tedi mine in Papua New Guinea, mineral development in Wisconsin, and uranium mining in Australia provide several key insights applicable to the case of Northern Canada. ${ }^{28}$ One important theme to emerge from these investigations is the fact that aboriginal communities themselves often perceive conflicts over mining not as an issue of distributional equity but as part of the much broader injustices associated with their historical experience of colonialism. Although aboriginal communities maintain complex and variable relationships to mining companies, with some actively promoting the economic benefits of mineral development on traditional lands, for many groups discourses of development and progress through mineral extraction are strongly associated with their historical memory of dispossession, social dislocation, and the disruption of

${ }^{24}$ W.O. Mackasey. "Abandoned Mines in Canada." Un-
published report prepared for MiningWatch Canada by WOM
Geological Associates, Inc. (2000), 7.
${ }^{25}$ Laura Pulido, "A Critical Review of the Methodology of
Environmental Racism Research," Antipode 28 (1996), 142-59;
Michael K. Hieman, "Race, Waste, and Class: New Perspectives
on Environmental Justice," Antipode 28 (1996), 111-121; David N.
Pellow, "Environmental Inequality Formation: Toward a Theory
of Environmental Injustice," American Behavioral Scientist 43
(2000), 581-601; David R. Simon, "Corporate Environmental
Crimes and Social Inequality: New Directions for Environmental
Justice Research," American Behavioral Scientist 43 (2000), 633-645.
For an overview, see also Luke Cole. From the Ground Up: En-
vironmental Racism and the Rise of the Environmental Justice Move-
ment. (New York: New York University Press, 2000).
26rancis O. Adeola, "Cross-National Environmental Injustice and Human Rights Issues: A Review of Evidence in the Developing World," American Behavioral Scientist 43 (2000), 686-706; Julian Agyeman, Robert D. Bullard, and Bob Evans, "Exploring the Nexus: Bringing Together Sustainability, Environmental Justice and Equity," Space and Polity 6 (2002), 77-90; Julian Agyeman, Robert D. Bullard, and Bob Evans (eds.). Just Sustainabilities: Development in an Unequal World. (London: Earthscan, 2003); Tina Loo, "Disturbing the Peace: Environmental Change and the Scales of Justice on a Northern River," Environmental History 12 (2007), 895-919; George Towers, "Applying the Political Geography of Scale: Grassroots Strategies and Environmental Justice," Political Geography 52 (2000), 23-36; Robert W. Williams, "Environmental Justice in America and its Politics of Scale," Political Geography 18 (1999), 49-73.

${ }^{27}$ Nicholas Low and Brendan Gleeson. Justice, Society and Nature: An Exploration of Political Ecology. (London: Routledge, 1998), 131.

${ }^{28}$ Saleem H. Ali. Mining, the Environment, and Indigenous Development Conflicts. (Tucson: University of Arizona Press, 2003); Subhabrata Bobby Banerjee, "Whose Land Is It Anyway? National Interest, Indigenous Stakeholders, and Colonial Discourses," Organization and Environment, 13 (March 2000), 3-38; Al Gedicks. Resource Rebels: Native Challenges to Mining and Oil Companies. (Cambridge, MA: South End Press, 2001); Robert Wesley Heber, "Indigenous Knowledge, Resources Use, and the Dene of Northern Saskatchewan," Canadian Journal of Development Studies 26 (2005), 247-256; Richard Howitt. Rethinking Resource Management: Justice, Sustainability and Indigenous Peoples. (London: Routledge, 2001); Marcus B. Lane and E. Rickson Roy, "Resource Development and Resource Dependency of Indigenous Communities: Australia's Jawoyn Aborigines and Mining at Coronation Hill," Society and Natural Resources 10 (1997), 121-142; Nicholas Low and Brendan Gleeson, "Situating Justice in the Environment: The Case of BHP at the Ok Tedi Copper Mine," Antipode 30 (1998), 201-226; Joan Martinez-Alier, "Mining Conflicts, Environmental Justice, and Valuation," Journal of Hazardous Materials, 86 (2001), 153-170. 
traditional lifestyles and land uses. ${ }^{29}$ Resistance to the environmental problems associated with mining developments is thus coupled with the broader themes of cultural survival and sovereignty over traditional lands. As some observers have pointed out, even in nominally post-colonial societies, struggles over the environmental impacts of mining activity in marginal aboriginal lands do not manifest themselves solely as local conflicts, but as individual nodes of resistance to the larger global system of capital accumulation and neo-colonialism. ${ }^{30}$

\section{THE POLITICAL ECOLOGY OF NORTHERN MINING}

As in other parts of the globe, mining activity in Northern Canada in the early to mid-twentieth century proceeded hand in hand with state-supported colonization efforts and capital expansion. Although Canada assumed sovereignty over its vast northern territories in 1870, the conclusion of treaties between northern aboriginal groups and the Canadian government awaited the Klondike gold rush (Treaty 8, 1899) and the discovery of oil at Norman Wells, NWT (Treaty 11, 1921). ${ }^{31}$ Thereafter, industrial mining was one of the primary means (along with hydrocarbon development) by which the Canadian government attempted to advance a modernization agenda in the North, in effect colonizing the region through the subsidized provision of infrastructure and capital (i.e., money for railways, roads, airstrips, etc.) to support the development of private sector and strategic military mega-projects. In the Canadian national imagination, the North was (as one mining geologist had it) "a vast, empty, cold, country": both an unpopulated wilderness and a theatre of colonial development and expansion fueled by resource extraction. ${ }^{32}$ This attitude received its fullest political expression in Prime Minister John Diefenbaker's government's 1958 declaration of a northern vision for industrial development in Canada. ${ }^{33}$ In environmental terms, the structural racism inherent in discourses of colonialism and development was most visibly manifest not through siting decisions per se, but through the erasure of aboriginal territorial interests and concerns about the ecological and social impacts of resource developments, including mining. ${ }^{34}$ Northern mining projects produced, as Martinez-Alier has argued in a global context, conflicts over the valuation of local resources: in this case, whether Northern Canada was destined to become a resource frontier serving national security and development imperatives, or a homeland where aboriginal communities would exercise some measure of sovereignty (based on treaty rights and long-term occupancy) over their local resources. ${ }^{35}$

Situating northern mining within this nexus of capitalism, colonialism, and aboriginal rights suggests that mining impacts, and by extension similar cases of environmental degradation in North America, could profit greatly from the insights offered by a historically grounded environmental justice/political ecology approach (which we will refer to, following Brannstrom and Offen, as historical political ecology). ${ }^{36}$ Although predominantly focused on land- and resource-use conflicts in the Third
World rather than waste disposal or anti-toxics activism, historical political ecology integrates environmental histories of biophysical change with an analysis of the ideological and economic dimensions of resource distribution and exploitation-in Blaikie and Brookfield's influential formulation, combining "the concerns of ecology and a broadly defined political economy. ${ }^{137}$ Major themes include the restriction of aboriginal people's access to resources by colonial and commercial elites, the differential impact of environmental degradation on subsistence-oriented communities, the exclusion of local people from national parks and nature preserves, and grassroots rural resistance to state-sanctioned conservation and re-

${ }^{29}$ John Borrows, "Living Between Water and Rocks: First Nations, environmental planning and democracy," University of Toronto Law Journal 47 (1997), 417-468; see also Fiona D. Mackenzie and Simon Dalby, "Moving Mountains: Community and Resistance in the Isle of Harris, Scotland, and Cape Breton, Canada," Antipode 35 (2003), 309-333. Heather Goodall, "Indigenous Peoples, Colonialism, and Memories of Environmental Injustice." In Sylvia Hood Washington, Paul C. Rosier, Heather Goodall (eds.). Echoes from the Poisoned Well: Global Memories of Environmental Injustice. (Oxford: Lexington Books, 2006), 74-75; Howitt, Rethinking Environmental Management; Noriko Ishiyama, "Environmental Justice and American Indian Tribal Sovereignty: Case Study of a Land-Use Conflict in Skull Valley, Utah," Antipode 35 (2003), 119-39; Dana E. Powell, "Technologies of Existence: The Indigenous Environmental Justice Movement," Development, 49 (2006), 125-132.

${ }^{30}$ David Schlosberg, "Reconceiving Environmental Justice: Global Movements and Political Theories," Environmental Politics 13 (Autumn 2004), 517-540.

${ }^{31}$ The connections between industrial development and territorial dispossession are amply documented for the Dene of the NWT in Kerry Abel. Drum Songs: Glimpses of Dene History. (Montreal and Kingston: McGill-Queen's University Press, 1993), Chapters 8-11. Largely to avoid the potential for land alienation, aboriginal people in the Yukon territory, however, were not offered treaties: see Coates, Best Left As Indians, 162-163.

${ }^{32}$ W.O. Kupsch, "Surveying the geology of a vast, empty, cold country." In Ellen Drake and William Jordan (eds.). Geologists and Ideas: A history of North American geology. (Boulder, CO: Geological Society of North America, 1985). This attitude is further evidenced in a Royal Society of Canada symposium volume: V.W. Bladen (ed.). Canadian Population and Northern Colonization. (Toronto: University of Toronto Press, 1962). For critiques, see Shelagh Grant, "Northern Nationalists: Visions of a New North, 1940-1950." In Kenneth R. Coates and William R. Morrison, (eds.). For Purposes of Dominion: Essays in honour of Morris Zaslow. (North York, ON: Captus University Publications, 1989); Shelagh Grant, "Arctic Wilderness and Other Mythologies," Journal of Canadian Studies 32 (1998), 27-42.

${ }^{33}$ The Diefenbaker government was in power from 1958 to 1963. A northern vision of industrial development and expansion was a key plank of their initial election platform (and a key contributor to the victory). For an overview, see Rea, The Political Economy of Northern Development, and Frances Abele, "Canadian Contradictions: Forty Years of Northern Political Development," Arctic 40 (1987), 310-320.

${ }^{34}$ Abel, Drum Songs, chapter 11.

${ }^{35}$ See Martinez-Alier, "Mining Conflicts, Environmental Justice, and Valuation."

${ }^{36}$ Christian Brannstrom, "What Kind of History for What Kind of Political Ecology?" Historical Geography, 32 (2004), 71-88; Karl Offen, "Historical Political Ecology: An Introduction," Historical Geography, 32 (2004), 7-18.

${ }^{37}$ Piers M. Blaikie and Harold C. Brookfield. Land Degradation and Society. (London: Methuen, 1987), 17. 
source development projects. ${ }^{38}$ Historical political ecology examines these themes through a combination of archival methods and a "field-informed interpretation of societynature relations in the past... how and why those relations have changed (or not changed) over time and space, and the significance of those interpretations for improving social justice and nature conservation today. ${ }^{\prime 39}$ Such a perspective incorporates a normative dimension that strongly echoes the movement orientation of much environmental justice scholarship. ${ }^{40}$

From a theoretical perspective, accounts of the historical-geographical conditions and processes implicated in the discursive and material production of nature and landscape are central to understanding resource conflicts within a political ecology framework. Although much political ecology scholarship is focused on contemporary environmental conflicts, explicitly historical accounts seek to examine regional histories and political economies of resource development and environmental change. Amongst geographers, a strong Marxist political economy tradition undergirds this perspective, which seeks to analyse and critique how the capitalist production of nature is implicated in processes of uneven geographical development. ${ }^{41}$ This tradition is enhanced and extended through examinations of the ideologies and discourses that facilitate resource development and environmental transformations-such as notions of progress and modernization, or the discursive construction of resource peripheries as "primary-commodity supply zones." ${ }^{42}$ Perhaps the most sustained efforts to theorize and investigate the historical dimensions of political ecology have emerged from studies of colonial appropriations of land and resources, such as Andrew Sluyter's model of "material-conceptual landscape transformation."43 Sluyter, Neumann, and others have shown how colonial myths of wilderness and pristine nature both rested upon and facilitated the physical erasure of indigenous occupation and livelihood strategies in the name of the improvement and/or preservation of nature (which, as Neil Smith argues, are either side of the same developmentalist coin). ${ }^{44}$ These approaches complement the work of environmental historians such as William Cronon, whose work traces the links between environmental change, resource management practices, and colonial dispossession. ${ }^{45}$ In important ways, then, environmental-historical and political ecology scholarship both draw from and contribute to the broader efforts of postcolonial scholars to investigate the material and discursive processes implicated in colonialism.

Recent scholarship on environmental conflict in North America has called for the development of a "First World" political ecology, which recognizes that "colonialism's traces are still clearly inscribed in patterns of resource use, access, and control in many First World locations. ${ }^{\prime 46}$ As Caroline Desbiens demonstrated in her study of hydroelectric dam controversies in Quebec, "in contexts where past colonial relations continue to unfold into the present, struggles for political recognition are fought in the environmental arena through culturally specific constructions of nature, land and resource management." ${ }^{47}$ These struggles, we argue, are in turn refracted through longstanding historical conflicts over natural resources and socio-environmental transformations rooted in colonial relations. Northern Canada provides an almost ideal

${ }^{38}$ Important introductions to the field of political ecology include Paul Robbins. Political Ecology: A Critical Introduction. (Oxford: Blackwell, 2004); Karl S. Zimmerer and J. Bassett Thomas, "Approaching Political Ecology: Society, Nature, and Scale in Human-Environment Studies." In Karl S. Zimmerer and Thomas J. Bassett (eds.). Political Ecology: An Integrative Approach to Geography and Environment-Development Studies. (New York: Guilford Press, 2003); Peter Walker, "Politics of Nature: An Overview of Political Ecology," Capitalism, Nature, Socialism 9 (March 1998), 131-144.

${ }^{39}$ Offen, "Historical Political Ecology: An Introduction," 21.

${ }^{40}$ James McCarthy, "First World Political Ecology: Directions and Challenges," Environment and Planning A 27 (2005), 955-56.

${ }^{41}$ See discussions in Robbins, Political Ecology, chapter 3; Michael Watts and Richard Peet, "Liberating Political Ecology." In Richard Peet and Michael Watts (eds.). Liberation Ecologies: Environment, Development, Social Movements. 2nd ed. (London: Routledge, 2004); Roger Keil, David V.J. Bell, Peter Penz, and Leesa Fawcett, "Editors' Introduction: Perspectives on Global Political Ecology." In Roger Keil, David V.J. Bell, Peter Penz, and Leesa Fawcett (eds.). Political Ecology: Global and Local. (London: Routledge, 1998).

${ }^{42}$ Erik Swyngedouw, "Modernity and Hybridity: Nature, Regeneracionismo, and the Production of the Spanish Waterscape, 1890-1930," Annals of the Association of American Geographers 89 (1999), 443-465; Gavin Bridge, "Resource triumphalism: postindustrial narratives of primary commodity production," Environment and Planning A 33 (2001), 2149-2173.

${ }^{43}$ Andrew Sluyter, "Colonialism and Landscape in the Americas: Material-Conceptual Landscape Transformations and Continuing Consequences," Annals of the Association of American Geographers 91 (2004), 410-429; Andrew Sluyter. Colonialism and Landscape: Postcolonial Theory and Applications. (Lanham, MD: Rowman and Littlefield, 2002).

${ }^{44}$ Neil Smith. Uneven Development: Nature, capital, and the production of space, 3rd ed. (Athens: University of Georgia Press, 2008 [1984]), 26-29; Roderick Neumann, "Nature-State-Territory: Toward a Critical Theorization of Conservation Enclosures." In Richard Peet and Michael Watts (eds.). Liberation Ecologies: Environment, Development, Social Movements. 2nd ed. (London: Routledge, 2004); Bruce Willems-Braun, "Buried Epistemologies: The Politics of Nature in (Post)Colonial British Columbia," Annals of the Association of American Geographers 82 (1997), 3-31.

${ }^{45}$ William Cronon. Changes in the Land: Indians, Colonists and the Ecology of New England. (New York: Hill \& Wang, 1983); Joseph E. Taylor III. Making Salmon: An Environmental History of the Northwest Fisheries Crisis. (Seattle: University of Washington Press, 1999); Louis Warren. The Hunter's Game: Poachers and Conservationists in Twentieth Century America. (New Haven: Yale University Press, 1999); Richard Grove. Green Imperialism: Colonial Expansion, Tropical Island Edens and the Origins of Environmentalism, 1600-1860. (Cambridge: Cambridge University Press, 1995).

${ }^{46}$ James McCarthy, "First World Political Ecology: Lessons from the Wise Use Movement," Environment and Planning A 34 (2002), 1281-1302; Richard A. Schroeder, Kevin St. Martin, and E. Albert Katherine, "Political Ecology in North America: Discovering the Third World Within?" Geoforum 37 (2006), 163-168; Peter A. Walker, "Reconsidering 'Regional' Political Ecologies: Toward a Political Ecology of the Rural American West," Progress in Human Geography 27 (2003), 7-24.

${ }^{47}$ Caroline Desbiens, "Producing North and South: A Political Geography of Hydro Development in Quebec," The Canadian Geographer 48 (2004), 101-118. See also Mackenzie and Dalby, "Moving Mountains: Community and Resistance in the Isle of Harris, Scotland, and Cape Breton, Canada." 
setting for applying a historical political ecology analysis in a First World context because, as with many colonized environments in Asia and Africa, the region was never subjected to a large land-based settlement rush and thus has maintained majority or large minority aboriginal populations in many areas to the present day. Yet many of the same conflicts between the state and aboriginal hunters over conservation policies (i.e., protected areas and hunting regulations) are woven into the history of Northern Canada in similar ways to the Third World. ${ }^{48}$ As with many commercial colonies in the Third World, the designation of the region as an industrial resource frontier fostered rapid economic and environmental change that, historically, provided few benefits for the region's aboriginal inhabitants. Understood from a political ecology perspective, the landscapes produced by industrial development in the North-resource towns, transportation networks, and disturbed local environments-became material expressions of the power and priorities of southern Canadian institutions, technologies, and ideologies.

The historical political ecology approach also helps answer critics of environmental justice research who bemoan an excessively quantitative or functional definition of the field. As mentioned above, many scholars have argued that in order to comprehend environmental justice claims within their historical-geographical contexts, it is important to move beyond simplistic "siting" perspectives that appeal to problematic universalizing or bureaucratic definitions of justice and equity. ${ }^{49}$ Environmental justice research shares with political ecology an emphasis on the uneven geographical distribution of the causes and effects of environmental problems; what historical political ecology, in particular, also highlights is the origin of these maldistributions within larger-scale cultural and economic processes such as colonialism and underdevelopment, and the connections between environmental degradation and closely related social and economic inequities. This perspective also links activism around environmental questions to aboriginal struggles for land and treaty rights and agitation for self-determination. ${ }^{50}$

At the same time, historically grounded research within a broadly defined environmental justice framework offers a critical means to understand more fully the variety of causal factors that produce environmental inequities in particular places. In separate calls for more historical research within the field of environmental justice, Egan and Holifield have both claimed that the qualitative and narrative approach that dominates historical studies offers the best means to capture the sometimes subtle and complex processes that cause environmental injustices. ${ }^{51}$ Historical case-study work bears this argument out. Hurley, Stroud, and Boone and Modarres have all produced important studies of U.S. urban environments that suggest environmental injustices are less the product of a singular racist policy initiative, and more the result interwoven factors that may include restrictive housing policies, historical population migrations, zoning decisions made in accordance with available industrial land, and class and race divisions produced under industrial capitalism. ${ }^{52}$ Though the environmental justice issues in urban environments are very different than those faced by aboriginal communities adjacent to mines in the Canadian North, the narrative quality of historical research can similarly account for the myriad ways in which environmental racism was manifest through mining activity (i.e., the willful ignorance of hunting and trapping sites, the absence of aboriginal employment policies, inadequate mine waste facilities, etc.), without subsuming the unique experience of affected communities within a narrow definition of what constitutes environmental injustice.

Finally, an examination of northern mining within a historical political ecology framework allows scholars to contextualize global narratives of mining and aboriginal people within a long-established political economy tradition in Canada. This body of critical scholarship (most readily identified with Harold Innis) draws on similar themes to political ecology such as dependency, the vulnerability of remote resource-based communities to the vagaries of international capital, and uneven geographical development associated with staples (i.e., primary resource) production in Canada's hinterland regions. ${ }^{53}$ While Innis' work on northern mining tended to focus on instant towns rather than aboriginal communities, his

${ }^{48}$ John Sandlos. Hunters at the Margin: Wildlife Conservation in the Northwest Territories. (Vancouver: UBC Press, 2007); Peter Kukchyski and Frank Tester. Kiumajut (Talking Back): Game Management and Inuit Rights, 1900-70. (Vancouver: UBC Press, 2007); Roderick P. Neumann. Imposing Wilderness: Struggles Over Livelihood and Nature Preservation in Africa. (Berkeley: University of California Press, 1998).

${ }^{49}$ See also David Harvey. Justice, Nature, and the Geography of Difference. (Cambridge, Mass: Blackwell, 1996), chapter 13.

${ }^{50}$ On these connections, see Howitt, Rethinking Resource Management; $\mathrm{Al}$ Gedicks, "Racism and Resource Colonization." In Daniel Faber (ed.). The Struggle for Ecological Democracy. (New York: Guilford Press, 1998); Ishiyama, "Environmental Justice and American Indian Tribal Sovereignty"; Nicholas C. Zaferatos, "Environmental Injustice in Indian Country: Dumpsite Remediation on the Swinomish Indian Reservation," Environmental Management 38 (2006), 896-909.

${ }^{51}$ Michael Egan, "Subaltern Environmentalism in the United States: A Historiographic Review," Environmental and History 8 (2002): 21-41; Ryan Holifield, "Defining Environmental Justice and Environmental Racism," Urban Geography 22 (2001), 78-90.

${ }^{52}$ Andrew Hurley. Environmental Inequalities: Class, Race and Industrial Pollution in Gary, Indiana, 1945-1980. (Chapel Hill: University of North Carolina Press, 1995); Ellen Stroud, "Troubled Waters in Ecotopia: Environmental Racism in Portland, Oregon," Radical History Review 74 (1999), 65-95; Christopher G. Boone and Ali Modarres, "Neighborhood in Los Angeles County: A Historical Examination of Environmental Inequity," Urban Affairs Review 35 (1999), 163-87.

${ }^{53}$ Harold A. Innis. Settlement and the Mining Frontier. (Toronto: Macmillan, 1936); Harold A. Innis. The Problems of Staple Production in Canada. (Toronto: Ryerson Press, 1933); John H. Bradbury, "Towards an Alternative Theory of Resource-Based Town Development in Canada," Economic Geography 55 (1979), 147-166; Jody Berland, "Space at the Margins: Critical Theory and Colonial Space after Innis." In Charles R. Acland and William J. Buxton (eds.). Harold Innis in the New Century. (Montreal and Kingston: McGill-Queen's University Press, 1999); Mary Louise McAllister, "Shifting Foundations in a Mature Staples Industry: A Political Economic History of Canadian Mineral Policy," Canadian Political Science Review 1 (June 2007), 73-90. 
critique of the single-minded exploitation of raw resources to serve metropolitan interests at the expense of local economic development strongly influenced debates around northern development in the 1970s. At the same time, aboriginal appeals for political recognition during the environmental assessment of the Mackenzie Valley Pipeline proposal-the landmark 1974-1977 Berger Inquiry-were embedded within the global struggle against colonialism, aboriginal rights to traditional lands, and the long term sustainability of the North as a homeland. The resulting Dene Declaration became one of the first explicit statements of aboriginal opposition to northern megadevelopment from the standpoint of what we would now describe as political ecology. ${ }^{54}$

Without a doubt, the struggle for political recognition and control that began with the Berger Inquiry has been partly achieved in the past thirty years through comprehensive land claims settlements covering large areas of the territorial north (giving First Nations limited control over sub-surface development), aboriginal inclusion in environmental assessments, and the negotiation of impact and benefit agreements for major resource developments. With renewed industry commitments to sustainable mining and its social license to mine, consultation with aboriginal communities over the environmental, social, and economic implications of mining has become a required part of development proposals. ${ }^{55}$ Indeed, many northern aboriginal groups now actively promote mineral and hydro-carbon development as a key economic development strategy. Nonetheless, the diamond rush of the 1990s and the subsequent development of the Ekati and Diavik mines in the Central Arctic raised concerns in several Dene communities about the token nature of their participation in environmental assessments, the percieved pro-development stance of the environmental assessment boards, and the federal government's insistence that environmental assessments consider only site-specific impacts rather than cumulative or broad-scale regional environmental changes from multiple mining projects. ${ }^{56}$ Moreover, in the last halfdecade or so (before the recent economic downturn hit the commodities sector), mineral exploration and development in Canada has reached new peaks. In some cases (such as at Mayo, Port Radium, and Pine Point), defunct mining operations are being investigated for possible reopening, often alongside ongoing environmental monitoring and remediation from previous bouts of mineral exploitation. While the political landscape of aboriginal rights and interests in northern development has shifted significantly since the 1970 s, many concerns remain about the environmental and social consequences of the new mineral and hydrocarbon rush in the region. For many, unease with new development stems from an omnipresent history-etched into local memories and local landscapes-of environmental degradation that has accompanied mining mega-projects. ${ }^{57}$

Such historical perspectives are critical to understanding the environmental justice dimensions of past and contemporary mining developments in Northern Canada. Indeed, the integration of these local-scale historical narratives of environmental dislocation with a macro-scale analysis of themes from the political economy and political ecology literatures offers crucial theoretical perspectives from which to analyze contemporary mining developments in Northern Canada as part of a broad environmental justice agenda. In more general terms, this approach can also help scholars and activists transcend the many boundaries - conceptual, political, regional, and disciplinary - that have prevented a full analysis of the many manifestations of indigenous environmental justice struggles within the First World setting of North America.

$$
\begin{array}{r}
\text { Address correspondence to: } \\
\text { Arn Keeling } \\
\text { Department of Geography } \\
\text { Memorial University of Newfoundland } \\
\text { St. John's, NL } \\
\text { Canada }
\end{array}
$$

E-mail: akeeling@mun.ca

${ }^{54}$ Thomas Berger. Northern Frontier, Northern Homeland: The Report of the Mackenzie Valley Pipeline Inquiry: Volume One. (Toronto: James Lorimer and Co., 1977); Mel Watkins (ed.). Dene Nation: The Colony Within. (Toronto: University of Toronto Press, 1977); Paul Sabin, "Voices from the Hydrocarbon Frontier: Canada's Mackenzie Valley Pipeline Inquiry (1974-1977)," Environmental History Review 19 (Spring 1995), 17-48.

${ }^{55}$ Lise-Aurore Lapalme. The Social Dimension of Sustainable Development in the Mining Industry: A Background Paper. (Ottawa: Public Works and Government Services Canada, 2003); MaryLouise McAllister and Cynthia Jacqueline Alexander. A Stake in the Future: Redefining the Canadian Mineral Industry. (Vancouver: UBC Press, 1997); Alistair MacDonald. Industry in Transition: A Profile of the North American Mining Sector. (Winnipeg: International Institute for Sustainable Development 2002).

${ }^{56}$ For an overview, see Ellen Bielawski. Rogue Diamonds: Northern Riches on Dene Lands. (Toronto: Douglas \& McIntyre, 2003).

${ }^{57}$ For example, aboriginal testimony during the environmental assessment of the proposal to reopen the Pine Point mine was strongly informed by the previous negative experience of mining development in the region. See Mackenzie Valley Environmental Impact Review Board. Report of Environmental Assessment and Reasons for Decision on Tamerlane Ventures Inc.'s Pine Point Pilot Project. EA0607-002, February 22, 2008. 

This article has been cited by:

1. ARN KEELING. 2010. 'Born in an atomic test tube': landscapes of cyclonic development at Uranium City, Saskatchewan. The Canadian Geographer / Le Géographe canadien 54:2, 228-252. [CrossRef] 